\title{
$\gamma \delta$ T Lymphocytes: An Effector Cell in Autoimmunity and Infection
}

\author{
Carolina Maiumi Shiromizu ${ }^{1}$ and Carolina Cristina Jancic ${ }^{1,2 *}$ \\ 1 Laboratorio de Inmunidad Innata, Instituto de Medicina Experimental (IMEX) - CONICET, Academia Nacional de Medicina, \\ Buenos Aires, Argentina, ${ }^{2}$ Departamento de Microbiología, Parasitología e Inmunología, Facultad de Medicina, Universidad \\ de Buenos Aires, Buenos Aires, Argentina
}

\section{OPEN ACCESS}

Edited by:

Gustavo Javier Martinez,

Rosalind Franklin University of Medicine and Science, United States

Reviewed by: Jun-ichi Kira, Kyushu University, Japan Irah L. King,

McGill University, Canada

*Correspondence:

Carolina Cristina Jancic cjancic@gmail.com

Specialty section:

This article was submitted to $T$ Cell Biology,

a section of the journal

Frontiers in Immunology

Received: 29 May 2018 Accepted: 26 September 2018 Published: 16 October 2018

Citation:

Shiromizu CM and Jancic CC (2018) $\gamma \delta$ T Lymphocytes: An Effector Cell in Autoimmunity and Infection.

Front. Immunol. 9:2389.

doi: 10.3389/fimmu.2018.02389 $\gamma \delta T$ cells are non-conventional lymphocytes which show several properties of innate immune cells. They present a limited TCR repertoire and circulate as cells with a pre-activated phenotype thus being able to generate rapid immune responses. $\gamma \delta \mathrm{T}$ cells do not recognize classical peptide antigens, their TCRs are non-MHC restricted and they can respond to pathogen-associated molecular patterns and to cytokines in absence of TCR ligands. They also recognize self-molecules induced by stress, which indicate infection and cellular transformation. All these features let $\gamma \delta \mathrm{T}$ cells act as a first line of defense in sterile and non-sterile inflammation. $\gamma \delta$ T cells represent $1-10 \%$ of circulating lymphocytes in the adult human peripheral blood, they are widely localized in non-lymphoid tissues and constitute the majority of immune cells in some epithelial surfaces, where they participate in the maintenance of the epithelial barriers. $\gamma \delta \mathrm{T}$ cells produce a wide range of cytokines that orchestrate the course of immune responses and also exert high cytotoxic activity against infected and transformed cells. In contrast to their beneficial role during infection, $\gamma \delta T$ cells are also implicated in the development and progression of autoimmune diseases. Interestingly, several functions of $\gamma \delta$ T cells are susceptible to modulation by interaction with other cells. In this review, we give an overview of the $\gamma \delta$ T cell participation in infection and autoimmunity. We also revise the underlying mechanisms that modulate $\gamma \delta$ T cell function that might provide tools to control pathological immune responses.

Keywords: $\gamma \delta$ T lymphocytes, inflammation, autoimmunity, infection, innate cells

\section{INTRODUCTION}

$\gamma \delta \mathrm{T}$ cells are non-conventional $\mathrm{T}$ lymphocytes present in blood and tissues with a restricted TCR repertoire. During the ontogeny in the thymus, $\gamma \delta \mathrm{T}$ cells develop before $\alpha \beta \mathrm{T}$ lymphocytes and are abundant during the first weeks of fetal development. However, after birth, they constitute a minor fraction of thymocytes. This is similar in humans and rodents (1). In healthy adult humans, they represent $1-10 \%$ of the total circulating lymphocytes with a phenotype mainly CD4/CD8 double negative (2). They are found in high proportion in epithelial tissues, being particularly abundant in the intestine (3). In homeostatic conditions, $\gamma \delta \mathrm{T}$ cells can display a pre-activated and memory phenotype and the high frequency of these cells enables rapid responses without the presence of cognate TCR agonists and/or cellular expansion (1). $\gamma \delta \mathrm{T}$ cells can recognize many microorganisms and infected or transformed host cells (4) and exert a direct cytotoxic activity, which involves secretory, and non-secretory pathways, i.e., the release of granzymes and perforins and the engagement of Fas and TNF-related apoptosis-inducing ligand receptors, respectively 
(5-7). Moreover, $\gamma \delta \mathrm{T}$ cells can propitiate the healing of damaged tissues and maintain the epithelial integrity (8). They can also generate memory cells, hence acting like adaptive immune $T$ cells (9). Interestingly, and similar to conventional $\mathrm{T}$ lymphocytes, $\gamma \delta \mathrm{T}$ cells can differentiate into different effector profiles, and produce different chemokines and a wide array of cytokines including IFN- $\gamma$, TNF- $\alpha$, IL-17, IL-21, and IL-22 (10). Recently, it has been reported in a murine model that in adipose tissue $\gamma \delta \mathrm{T}$ cells are abundant and they participate in the regulation of body temperature, through the production of IL-17A and TNF$\alpha$, and through the maintenance of catecholamine sensitivity for lipolysis induction. Moreover, in adipose tissue, $\gamma \delta \mathrm{T}$ cells let the recruitment and homeostatic expansion of regulatory T cells (11).

Regarding the effector profiles in mice, $\gamma \delta \mathrm{T}$ cells complete their functional differentiation in the fetal thymus (12). It has been shown, that $\gamma \delta \mathrm{T}$ cells that bind antigens with low affinity will produce IL-17, while those that bind antigen with high affinity will secrete IFN- $\gamma$ (13). Another difference between human and mouse $\gamma \delta \mathrm{T}$ cells is their classification. In humans, $\gamma \delta \mathrm{T}$ cells are classified according to their $\mathrm{V} \delta$ gene segment used. Until now only three true $\mathrm{V} \delta$ genes exist: $\mathrm{V} \delta 1-3$; and seven functional $\mathrm{V} \gamma$ gene segments: $\mathrm{V} \gamma 2-5, \mathrm{~V} \gamma 8, \mathrm{~V} \gamma 9$, and $\mathrm{V} \gamma 11$. While in mice $\gamma \delta \mathrm{T}$ cell subsets are named according to the $\mathrm{V} \gamma$ chain used (14). Of note, the data describing the $\gamma \delta \mathrm{T}$ cell subsets of a particular species cannot be translated directly to another species because each repertoire is unique. The $\gamma \delta$ TCR repertoire is restricted and is associated with the tissue distribution (5). The limited $\gamma \delta$ TCR repertoire is consistent with their capacity to recognize conserved pathogen-derived antigens and self-molecules expressed under cellular stress conditions (5). Their tissue distribution and their capacity to recognize and rapidly respond to self- and non-self-conserved antigens allow them to act as the first line of defense in peripheral tissues (4). In humans, $\mathrm{V} \delta 1+\mathrm{T}$ cells are abundant in the epithelium $(8,15,16)$, they recognize molecules of the non-classical MHC family, either with or without loaded antigens, such as $\mathrm{CD} 1 \mathrm{a}, \mathrm{c}$ and $\mathrm{d}$; and the molecules induced by stress: MICA/B and ULBP (5). Beside, $\mathrm{V} \delta 3+\mathrm{T}$ cells are enriched in the liver and the intestine $(17,18)$. They can express CD4 or CD8 though the majority are double negative (CD4-CD8-). V $83+\mathrm{T}$ cells also express CD56, CD161, CD28, HLA-DR, and NKG2D, and some of them recognize CD1d and can exert cytotoxicity on CD1d+ target cells similar to V $81+$ $\mathrm{T}$ cells (19). In humans and non-human primates, $\gamma \delta \mathrm{T}$ cells bearing the V $\delta 2$ chain are the main subset present in peripheral blood and this $\delta$ chain is generally associated to the $V \gamma 9$. During infection, $\mathrm{V} \delta 2 \mathrm{~V} \gamma 9 \mathrm{~T}$ cells can be recruited to peripheral tissues where they contribute to the eradication of local infection (20).

Like $\alpha \beta$ T lymphocytes, the activation of $\gamma \delta \mathrm{T}$ cells through the TCR requires the participation of accessory molecules. CD27 and NKG2D have been identified as co-effectors of the TCR activation $(21,22)$, but there is no clear consensus about the accessory molecules involved. Strikingly, in the past few years, it has been described the participation of CD277 [Butyrophilin(BTN)3A1] as a phosphoantigen presenting molecule specific for $\mathrm{V} \gamma 9 \mathrm{~V} \delta 2$ TCR. According, phosphoantigen recognition is not restricted to the presentation in MHC molecules and it is independent of professional antigen presenting cells, but requires cellular contact and non-polymorphic presenting molecules (23). The main above mentioned functions reported for $\gamma \delta \mathrm{T}$ cells are summarized in Figure 1.

\section{$\gamma \delta$ T CELLS IN INFECTION}

$\gamma \delta \mathrm{T}$ cells are key effectors in the immune response against microorganisms. In many microbial infections, the number of $\gamma \delta$ $\mathrm{T}$ cells increases locally and/or systemically after a few days postinfection, being able to reach a $50 \%$ of the total circulating $\mathrm{T}$ cells (24). A hallmark of $\gamma \delta \mathrm{T}$ cells is that they can recognize a broad spectrum of endogenous and exogenous antigens widespread in nature, i.e., bacteria, protozoa, and infected or transformed host cells (4). To recognize these ligands, $\gamma \delta \mathrm{T}$ cells employ the TCRs and receptors such as TLRs, NOTCH, NKG2D $(1,24)$. The rapid effector responses elicited in infectious processes are similar to those generated by innate immune cells, a property related to their ability to be activated without an antigenic priming (5). $\gamma \delta \mathrm{T}$ cells can directly kill infected cells by releasing the content of cytotoxic granules and bacteriostatic or lytic molecules such as granulysin and defensins $(7,25)$. Furthermore, they have an indirect action on the elimination of microbes by producing cytokines that promote inflammation and by inducing the antibacterial functions of immune and epithelial cells (26). As we previously mentioned, $\gamma \delta \mathrm{T}$ cells can differentiate into different effector profiles depending on the pathophysiological context. They can produce IFN- $\gamma$ and TNF- $\alpha$ in response to intracellular pathogens, IL-4, IL-5, IL-13 during parasite immune responses, and IL-17 in defense against extracellular bacteria and fungi (27). Accordingly mice lacking this cell subset (TCR $\delta$ KO mice) are more susceptible to suffer infections by bacteria (Nocardia spp., Klebsiella spp., Listeria spp., Escherichia coli, Salmonella spp., Mycobacterium spp., and Pseudomonas spp.) and parasites (Plasmodium spp.), demonstrating a critical role of IL-17-producing $\gamma \delta \mathrm{T}$ cells in these processes (28). The basis of the effector function of this $\mathrm{T}$ cell subset is controlling neutrophil recruitment in inflamed tissues. Interestingly, at sites of inflammation, neutrophils not only exert their microbicidal activity but also regulate (inhibit or stimulate) $\gamma \delta \mathrm{T}$ cell functions, as it has been extensively demonstrated (29-31).

Microbial recognition by $\mathrm{V} \gamma 9 \mathrm{~V} \delta 2 \mathrm{~T}$ cells involves phosphoantigens which are non-peptidic low molecular weight antigens with phosphate moieties, which are not only produced by prokaryotic but also eukaryotic cells. However, microbes' phosphoantigens are extremely potent activators of $\mathrm{V} \gamma 9 \mathrm{~V} \delta 2 \mathrm{~T}$ cells in contrast to endogenous phosphoantigens i.e., isopentenyl pyrophosphate (IPP) which is 10,000 -folds less effective to induce cellular activation $(32,33)$. Noteworthy, eukaryotic cells under increased metabolic activity, can augment the production of IPP, i.e., tumor cells, and consequently activate $\gamma \delta \mathrm{T}$ cells efficiently (18). The phosphoantigen (E)-4-hydroxy-3-methylbut-2-enyl pyrophosphate (HMBPP), an intermediate of the non-mevalonate pathway, generated by many bacteria, among them Mycobacterium tuberculosis (Mtb), Mycobacterium bovis, Listeria monocytogenes, E. coli, Salmonella typhimurium, and certain parasites such as Plasmodium falciparum and Toxoplasma 


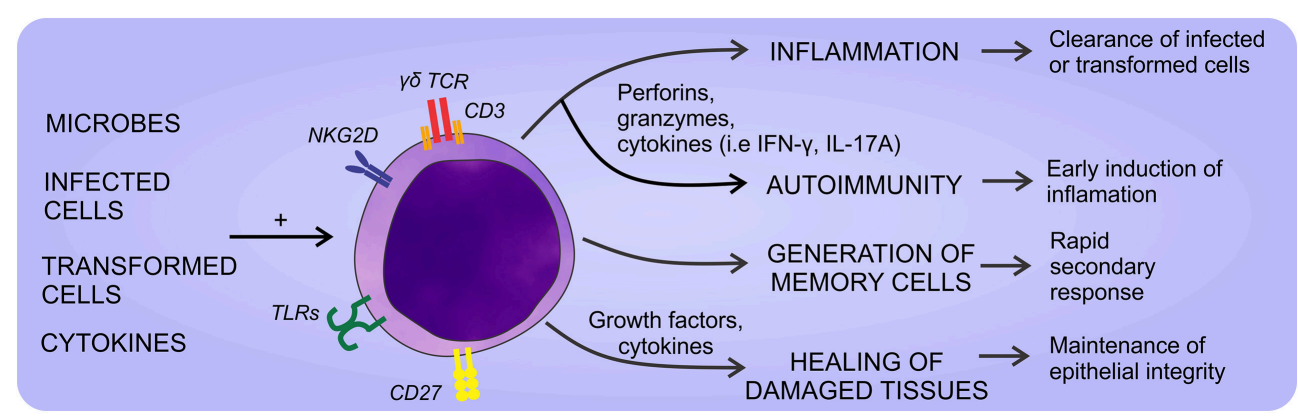

FIGURE 1 | General aspects of $\gamma \delta$ T cell physiology. $\gamma \delta$ T cells can sense a wide array of self- and non-self-stimuli that promote different responses. Thus, they can eliminate infected or transformed cells, heal damaged tissues, and eventually promote the development of autoimmune diseases if their response is exacerbated.

gondii is an extremely potent activator of $\mathrm{V} \gamma 9 \mathrm{~V} \delta 2 \mathrm{~T}$ cells $(33,34)$. Thanks to the presence of this metabolite, $\mathrm{V} \gamma 9 \mathrm{~V} \delta 2 \mathrm{~T}$ cells can be activated, proliferate and produce Th1-cytokines (IFN- $\gamma$ and TNF- $\alpha$ ) (29), thus mounting a rapid response against the microbes. Moreover, during Mtb or L. monocytogenes infections they produce IL-17 which prompts the recruitment of neutrophil and their immune response (35). In acute infections by Mtb and HMBPP-producing microbes, this cell subset expand and in re-infections they mount a secondary memory-like response (36). Furthermore, the production of IFN- $\gamma$ by stimulated$\mathrm{V} \gamma 9 \mathrm{~V} \delta 2 \mathrm{~T}$ cells may contribute to the immune response against $\mathrm{Mtb}$ as well as to control tuberculosis lesions since they are present in lung granuloma (37). $\mathrm{V} \gamma 9 \mathrm{~V} \delta 2 \mathrm{~T}$ cells also limit the development of intracellular Mtb by the action of perforins, granzymes, and granulysin (20). Additionally, they can promote airway CD8+ and Th1 CD4+ responses of conventional T cells specific for Mtb, through the production of IL-12 in response to phosphoantigen activation (20). In a non-human primate model of Mtb infection, ex vivo activation of $\mathrm{V} \gamma 9 \mathrm{~V} \delta 2 \mathrm{~T}$ cells by exogenous HMBPP up-regulates their IFN- $\gamma$ production. This treatment promotes the inhibition of IL-22 production, which is associated with severe lesions (38). These results might be helpful to develop novel therapeutic strategies to control Mtb infection and persistence and to induce the activation of immune cells by IFN- $\gamma$ in order to eliminate intracellular Mtb (Figure 2A).

In patients with viral infections, $\mathrm{V} \delta 3+\mathrm{T}$ cells are enriched. In hepatitis $\mathrm{C}$ virus (HCV) infections, it has been observed the expansion of several $\mathrm{V} 83+\mathrm{T}$ cell clones in peripheral blood (39). In the liver, these cells can mount a response against virus-infected hepatocytes and non-infected host cells, suggesting that they may contribute to the hepatic damage (40). Additionally, there is a higher frequency of IFN- $\gamma$-producing $\mathrm{V} \delta 1+$ cells, which correlates with disease evolution (41). During the immune response against viral infections, the recognition of non-classical MHC molecules by V $82-\mathrm{T}$ cells is determinant but also participate $\mathrm{V} \gamma 9 \mathrm{~V} \delta 2 \mathrm{~T}$ cells. It has been demonstrated that activated $\mathrm{V} \gamma 9 \mathrm{~V} \delta 2 \mathrm{~T}$ cells can inhibit sub-genomic $\mathrm{HCV}$ replication by the production of IFN- $\gamma(41,42)$. In the same way, patients suffering chronic hepatitis B virus (HBV) infection, have a reduction in the circulating $\mathrm{V} \delta 2+\mathrm{T}$ cells, in the production of IFN $-\gamma$ and in the cytotoxicity mediated by $\gamma \delta \mathrm{T}$ cells. These events correlate with the persistence of HBV infection (43). Noteworthy, in mouse models of infection by West Nile virus and herpes simplex virus type 2 , it has been shown that $\gamma \delta \mathrm{T}$ cells play a critical role in the generation of conventional CD8+ and $\mathrm{CD} 4+$ memory $\mathrm{T}$ cells, respectively $(44,45)$. Importantly, $\gamma \delta \mathrm{T}$ cells also participate in anti-viral response early in life. It has been reported that they can mount a functional immune response to cytomegalovirus infection during development in uterus, pointing out the key role of $\gamma \delta \mathrm{T}$ cells in fetal life (46).

Furthermore, $\gamma \delta \mathrm{T}$ cells participate in antifungal immunity. It has been reported that $\mathrm{V} \delta 1+\mathrm{T}$ cells can selectively respond to Candida albicans, by producing high levels of IL-17 (47).

Given the beneficial role of $\mathrm{V} \gamma 9 \mathrm{~V} \delta 2 \mathrm{~T}$ cells in the clearance of microbes, the in vivo effect of $\mathrm{T}$ cell activation by phosphoantigens administered exogenously was tested in primates (48). In an infection model induced by Yersinia pestis, phosphoantigen treatment provoked faster pathogen clearance and restoration of inflamed tissues (49). Moreover, during chronic viral infections, where $\mathrm{V} \gamma 9 \mathrm{~V} \delta 2 \mathrm{~T}$ cells are decreased and their functions are impaired $(50,51)$, it has been proposed the administration of phosphoantigens to help restore the $\gamma \delta \mathrm{T}$ cell functions. Furthermore, in a non-human primate model, it was reported that after administration of HMBPP, the plasma levels of IFN- $\gamma$ increased, and this effect was even higher when administered with IFN- $\alpha$ (52), showing a new approach to boost $\mathrm{V} \gamma 9 \mathrm{~V} \delta 2 \mathrm{~T}$ cell response in viral infection (Figure 2A). In this work authors also explored, in vitro, the effect of this combined therapy in $\mathrm{HCV}$-infected patients obtaining the same results (52).

\section{$\gamma \delta$ T CELLS IN AUTOIMMUNITY}

It is well established that IL-17A plays a crucial role in the development and progression of autoimmune diseases $(53,54)$. Even though the main source of IL-17A is the Th17 CD4+ $\alpha \beta$ T cell population, in the onset of autoimmune pathologies, innate immune cells, especially those belonging to the $\gamma \delta$ T cell subset, also contribute to the production of IL-17A (55). Human IL-17Aproducing $\gamma \delta \mathrm{T}$ cells are generated in the periphery and can be recruited to inflamed tissues where they accumulate $(56,57)$. This 
A

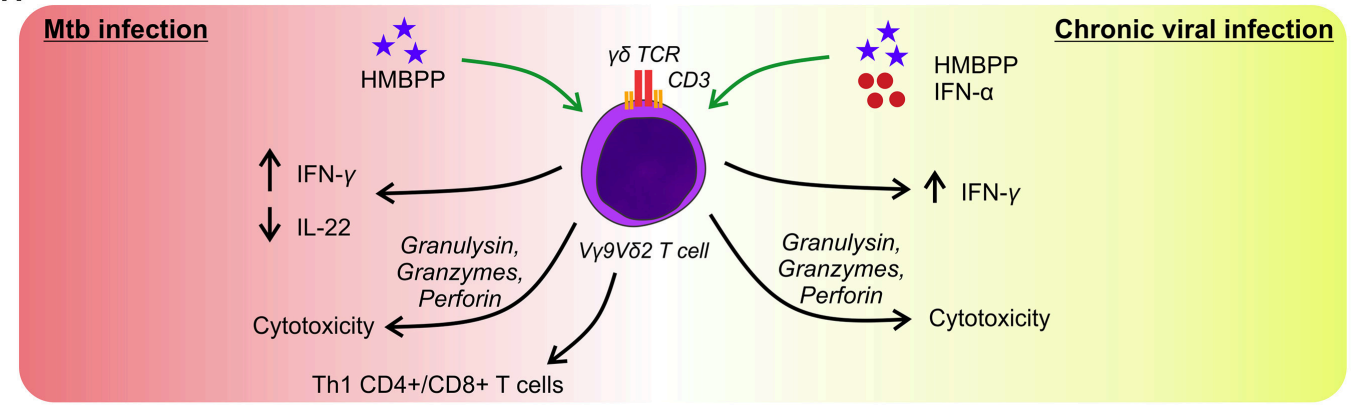

B

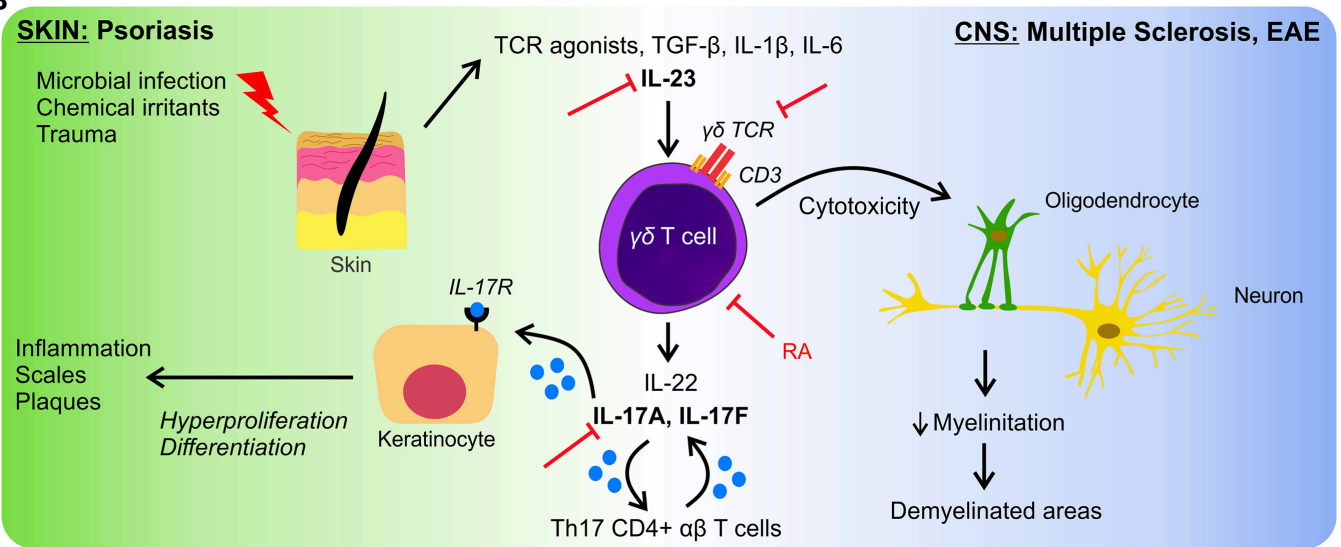

FIGURE 2 | $\gamma \delta$ T cells in infection and autoimmunity. (A) In response to Mtb infection, $\gamma \delta$ T cells produce inflammatory cytokines and exert cytotoxicity on infected cells (left side), similar effector functions are performed in response to several viruses (right side). But in chronic infections $\gamma \delta \mathrm{T}$ cells are less effective to control microbes. Green arrows represent the proposed approaches to boost the activation of $\gamma \delta$ T lymphocytes. (B) $\gamma \delta \mathrm{T}$ cells participate in the initiation and development of autoimmune diseases. As examples we represent pathologies in skin (left side) and in CNS (right side) both having in common an axis governed by the activation of $\gamma \delta$ T cells and by the production of IL-17 and IL-22. Figure shows different targets to block autoimmunity manifestations (red lines). RA, retinoic acid.

process takes place more rapidly compared to the activation of conventional T lymphocytes. In fact, $\gamma \delta \mathrm{T}$ cells can be activated in the absence of a cognate TCR ligand which allows them to be powerful early inducers of inflammation in autoimmune diseases. As demonstrated in vitro, several molecules are involved in the differentiation into the Th17 cytokine-profile, among them: TCR agonists, IL-1 $\beta$, IL-6, IL-23, and TGF- $\beta$ (57, 58). Interestingly, in patients with autoimmune liver disease such as autoimmune hepatitis, primary sclerosing cholangitis, or primary biliary cirrhosis, there is a significantly increase of $\gamma \delta$ $\mathrm{T}$ cells $(\mathrm{V} \delta 1+, \mathrm{V} \delta 2+$, and $\mathrm{V} \delta 3+)$ in peripheral blood and liver, supporting the participation of this subset in autoimmunity (18).

In the next paragraphs, we summarize the published data describing the role of $\gamma \delta$ T cells in psoriasis and multiple sclerosis as two examples of autoimmune diseases where the role of $\gamma \delta \mathrm{T}$ cells has been extensively studied.

\section{Autoimmunity in Skin}

In steady-state conditions, in the skin and the intestine, $\gamma \delta$ $\mathrm{T}$ cells are abundant and in conjunction with other immune cells, they act as sentinels and support the integrity of the epithelial barriers $(59,60)$. In human skin, local $\gamma \delta$ T cells display an oligoclonal repertoire governed by the expression of $\mathrm{V} \delta 1$ chain (61). A well-characterized inflammatory condition in the skin is psoriasis. It is an autoimmune disease which can be triggered by microbial infections, chemical irritants or trauma. Once the pathological process starts, the innate and adaptive immune system activate and result in the hyperproliferation and the aberrant differentiation of keratinocytes, a key step in the pathophysiology of psoriasis. There is also an increase in the levels of IFN- $\gamma$ and IL-23, which cause an immune-mediated dermatosis with skin lesions (62). In in vivo murine models of psoriasis induced by Imiquimod (TLR7/8 agonist) (63), $\gamma \delta \mathrm{T}$ cells were found to be necessary and sufficient to trigger skin lesions such as plaque formation, with a critical role of the axis IL-23/IL-17/IL-22. In fact, dermal $\gamma \delta \mathrm{T}$ cells easily proliferate and produce IL-17A, IL-17F, and IL-22 in response to IL-1 $\beta$ and IL23 stimulation (63). Remarkably, $\gamma \delta$ T cells have been proposed to initiate and precede the participation of conventional Th17 cells in psoriasis (64). In accordance, the genetic deletion of IL-17A, IL-17F, and IL-22 has shown to protect mice from Imiquimodinduced inflammation (65). Similarly, human dermal IL-17producing $\gamma \delta$ T cells appear to play a pathogenic role in psoriasis, as supported by evidence indicating an abundance of $\gamma \delta \mathrm{T}$ cells in skin biopsies from psoriasis patients, which upon stimulation with IL-23 in vitro, increase the IL-17 production to levels higher than $\alpha \beta$ T cells (63). Moreover, a reduction in peripheral blood $\mathrm{CLA}+\mathrm{CCR} 6+\mathrm{V} \gamma 9 \mathrm{~V} \delta 2+\mathrm{T}$ cells is observed in psoriasis patients 
which correlates with the severity of the pathology (66). The $\gamma \delta \mathrm{T}$ cells present in psoriasis skin are the $\mathrm{V} \delta 1+$ subset and the recently reported V $\delta 2+$ recruited from the blood. However, this finding remain controversial because $\mathrm{V} \gamma 9 \mathrm{~V} \delta 2+\mathrm{T}$ cells are normally rare in the dermis and exhibit a low capacity to produce IL-17 (67).

Interestingly, there is different preclinical and clinical data concerning the therapeutic strategies to treat psoriasis. Based on the components involved in the onset and progression of the disease, several molecular target has been studied. Remarkably, drugs that target IL-17 and IL-23 have shown notable efficacy (68), and some of them have been licensed to treat moderate and severe psoriasis $(68,69)$. Given the active role of $\gamma \delta \mathrm{T}$ cells in the development of autoimmunity, it is possible to speculate that the mentioned immunotherapies could act not only on conventional Th17 T cells but also on $\gamma \delta$ T lymphocytes because they express IL-23R and produce substantial quantities of IL-17A and IL-22 (Figure 2B).

\section{Autoimmunity in the Central Nervous System}

Even if the role of $\gamma \delta \mathrm{T}$ cells in multiple sclerosis (MS) has not been completely elucidated, numerous studies have found that $\gamma \delta \mathrm{T}$ cells are associated with this pathology. It has been reported that $\gamma \delta \mathrm{T}$ cells are cytotoxic against oligodendrocytes, which participate in the myelinization of neurons, therefore, $\gamma \delta$ $\mathrm{T}$ cells are implicated in the pathogenesis of MS and in its murine model, the experimental autoimmune encephalomyelitis (EAE) $(70,71)$. Noteworthy, it has been shown in patients suffering MS that $\gamma \delta \mathrm{T}$ cells accumulate in plaques and in chronically demyelinated areas of the central nervous system (CNS); and that IL-17A-producing $\gamma \delta \mathrm{T}$ cells increase in cerebrospinal fluids and in brain lesions $(72,73)$. As expected, in peripheral blood and CNS IL-17 is elevated (74). Recently it has been reported that circulating $\mathrm{V} \delta 2+\mathrm{T}$ cells are decreased in MS, and it was found a negative correlation between the percentages of $\mathrm{V} \delta 2+\mathrm{V} \gamma 9+\mathrm{T}$ cells and the disease severity (75). These findings led to suggest that the decrease in $\mathrm{V} \delta 2+\mathrm{T}$ cells impaired an effective control of auto-reactive $\alpha \beta \mathrm{T}$ lymphocytes (75). Additionally, in the CNS of mice with EAE, different subsets of $\gamma \delta \mathrm{T}$ cells were identified, among them the more abundant are: $\mathrm{V} \gamma 1, \mathrm{~V} \gamma 4, \mathrm{~V} \gamma 5$, and $\mathrm{V} \gamma 6$. These $\mathrm{T}$ cells infiltrate the brain and spinal cord in the early phases of EAE (10, 76-78). Interestingly, these subsets display different cytokine profiles, being the $\mathrm{V} \gamma 4+$ cells, the most abundant, and the ones that produce high levels of IL-17 $(76,79)$. Thus, $\gamma \delta \mathrm{T}$ cells could be the initiators of the inflammation and the inductors of Th17 cells by producing IL-17 and IL-21 in the early phases of EAE, causing the amplification of Th17 responses (10). Of note, $\gamma \delta \mathrm{T}$ cells also play a beneficial role during EAE, as mediators in the resolution of the inflammation. The subset involved in the tissue repairing phase is suggested

\section{REFERENCES}

1. Bonneville M, O’Brien RL, Born WK. $\gamma \delta \mathrm{T}$ cell effector functions: a blend of innate programming and acquired plasticity. Nat Rev Immunol. (2010) 10:467-78. doi: 10.1038/nri2781 to be $\mathrm{V} \gamma 1$, which could enhance the effector function of the regulatory $\mathrm{T}$ cells recruited (76), inhibit the differentiation to Th17 profile by the production of IFN- $\gamma$ (80), and trigger apoptosis of pathogenic CD4+ $\mathrm{T}$ cells through the Fas-FasL pathway.

In vivo experimental data support that $\gamma \delta \mathrm{T}$ cells have a deleterious role in MS, i.e., in the relapsing-remitting EAE model, treating mice with TCR $\delta$ depleting antibodies immediately before the onset or during the chronic phase of the disease produces a reduction of the disease (81); and in knockout mice for IL-1RI the severity of the EAE is very decreased, demonstrating the participation of IL- $1 \beta$ in the induction of IL17 -producing $\mathrm{T}$ cells (82). Interestingly, another molecule that could modulate $\gamma \delta \mathrm{T}$ cells in EAE is retinoic acid. Raverdeau and co-workers demonstrated that retinoic acid treatment suppressed the production of IL-17A by murine $\gamma \delta \mathrm{T}$ cells in vivo and they also observed a reduction in the number of $\gamma \delta \mathrm{T}$ cells infiltrating the CNS (83). Altogether, these data show the role of new molecules that could be used to design immunotherapeutic strategies, providing new alternatives to treat autoimmunity (Figure 2B).

\section{CONCLUDING REMARKS}

In the last few years, immunotherapies based on $\gamma \delta \mathrm{T}$ cells have gained a great interest, supported by the anti-microbial and anti-tumor capabilities of these cells. Interestingly, these cells could be suppressed when their response is exacerbated such as in autoimmunity or some infectious conditions or could be stimulated when their response is not optimal i.e., in chronic infections. Moreover, $\gamma \delta$ T cells can be manipulated ex vivo or in vivo to achieve an efficient immune response against infected or transformed cells. Nevertheless, further studies are necessary to address the most beneficial therapeutic approaches to modulate the self and non-self-immune response mediated by $\gamma \delta \mathrm{T}$ cells.

\section{AUTHOR CONTRIBUTIONS}

CS designed and performed figures and revised the manuscript. CJ wrote the manuscript.

\section{FUNDING}

CJ is funded by Consejo Nacional de Investigaciones Científicas y Técnicas and Agencia Nacional de Promoción Científica y Tecnológica-FonCyT (PICT2016/700).

\section{ACKNOWLEDGMENTS}

We thank Dr. Analia Trevani for critical reading of the manuscript.

2. Dar AA, Patil RS, Chiplunkar SV. Insights into the relationship between Toll Like Receptors and $\gamma \delta \mathrm{T}$ cell responses. Front Immunol. (2014) 5:366. doi: 10.3389/fimmu.2014.00366

3. Hoytema van Konijnenburg DP, Reis BS, Pedicord VA, Farache J, Victora GD, Mucida D. Intestinal epithelial and intraepithelial $\mathrm{T}$ cell 
crosstalk mediates a dynamic response to infection. Cell (2017) 171:1-12. doi: 10.1016/j.cell.2017.08.046

4. Hayday AC. $\gamma \delta$ cells: A right time and a right place for a conserved third way of protection. Annu Rev Immunol. (2000) 18:975-1026. doi: 10.1146/annurev.immunol.18.1.975

5. Vantourout $P$, Hayday A. Six-of-the-best: unique contributions of $\gamma \delta \mathrm{T}$ cells to immunology. Nat Rev Immunol. (2013) 13:88-100. doi: 10.1038/nri3384

6. Qin G, Mao H, Zheng J, Sia SF, Liu Y, Chan PL, et al. Phosphoantigenexpanded human $\gamma \delta \mathrm{T}$ cells display potent cytotoxicity against monocytederived macrophages infected with human and avian influenza viruses. J Infect Dis. (2009) 200:858-65. doi: 10.1086/6 05413

7. Dieli F, Troye-Blomberg, M, Ivanyi J, Fournié JJ, Krensky AM, Bonneville $\mathrm{M}$, et al. Granulysin-dependent killing of intracellular and extracellular Mycobacterium tuberculosis by V $\gamma 9 / \mathrm{V} \delta 2 \mathrm{~T}$ lymphocytes. J Infect Dis. (2001) 184:1082-5. doi: 10.1086/323600

8. Toulon A, Lionel B, Taylor KR, Tenenhaus M, Bhavsar D, Lanigan C, et al. A role for human skin-resident T cells in wound healing. J Exp Med. (2009) 206:743-50. doi: 10.1084/jem.20081787

9. McGinley AM, Edwards SC, Raverdeau M, Mills KH. Th17 cells, $\gamma \delta$ T cells and their interplay in EAE and multiple sclerosis. J Autoimmun. (2018) 87:97-108. doi: 10.1016/j.jaut.2018.01.001

10. Sutton CE, Lalor SJ, Sweeney CM, Brereton CF, Lavelle EC, Mills KH. Interleukin-1 and IL-23 induce innate IL-17 production from $\gamma \delta \mathrm{T}$ cells, amplifying Th17 responses and autoimmunity. Immunity (2009) 31:331-41. doi: 10.1016/j.immuni.2009.08.001

11. Kohlgruber AC, Gal-Oz ST, La Marche NM, Shimazaki M, Duquette D, Nguyen $\mathrm{HN}$, et al. $\gamma \delta \mathrm{T}$ cells producing interleukin-17A regulate adipose regulatory $\mathrm{T}$ cell homeostasis and thermogenesis. Nat Immunol. (2018) 19:464-74. doi: 10.1038/s41590-018-0094-2

12. Shibata K, Yamada H, Nakamura R, Sun X, Itsumi M, Yoshikai Y. Identification of CD25+ $\gamma \delta \mathrm{T}$ cells as fetal thymus-derived naturally occurring IL-17 producers. J Immunol. (2008) 181:5940-7. doi: 10.4049/jimmunol.181.9.5940

13. Jensen KDC, Su X, Shin S, Li L, Youssef S, Yamasaki S, et al. Thymic selection determines $\gamma \delta \mathrm{T}$ cell effector fate: antigen-naive cells make interleukin-17 and antigen-experienced cells make interferon gamma. Immunity (2008) 29:90-100. doi: 10.1016/j.immuni.2008.04.022

14. Adams EJ, Gu S, Luoma AM. Human $\gamma \delta \mathrm{T}$ cells: Evolution and ligand recognition. Cell Immunol. (2015) 296:31-40. doi: 10.1016/j.cellimm.2015.04.008

15. Chien YH, Meyer C, Bonneville M. $\gamma \delta \mathrm{T}$ cells: first line of defense and beyond. Ann Rev Immunol. (2014) 32:121-55. doi: 10.1146/annurev-immunol-032713-120216

16. Dunne MR, Eliott L, Hussey S, Mahmud N, Kelly J, Doherty DG, et al. Persistent changes in circulating and intestinal $\gamma \delta \mathrm{T}$ cell subsets, invariant natural killer $\mathrm{T}$ cells and mucosal-associated invariant $\mathrm{T}$ cells in children and adults with coeliac disease. PLOS ONE (2013) 4:e76008. doi: 10.1371/journal.pone.0076008

17. Kenna T, Golden-Mason L, Norris S, Hegarty JE, O’Farrelly C, Dohertye DG. Distinct subpopulations of $\gamma \delta \mathrm{T}$ cells are present in normal and tumor-bearing human liver. Clin Immunol. (2004) 113:56-63. doi: 10.1016/j.clim.2004.05.003

18. Doherty DG. Immunity, tolerance and autoimmunity in the liver: A comprehensive review. J Autoimmun. (2016) 66:60-75. doi: 10.1016/j.jaut.2015.08.020

19. Mangan BA, Dunne MR, O’Reilly VP, Dunne PJ, Exley MA, O'Shea $\mathrm{D}$, et al. Cutting Edge: CD1d restriction and Th1/Th2/Th17 cytokine secretion by human V83 T cells. J Immunol. (2013) 191:30-4. doi: 10.4049/jimmunol.1300121

20. Chen C, Yao S, Huang D, Wei H, Sicard H, Zeng G, et al. Phosphoantigen/IL2 expansion and differentiation of $\mathrm{V} \gamma 2 \mathrm{~V} \delta 2 \mathrm{~T}$ cells increase resistance to tuberculosis in nonhuman primates. PLoS Pathog. (2013) 9:e1003501. doi: 10.1371/journal.ppat.1003501

21. deBarros A, Chaves-Ferreira M, d'Orey F, Ribot JC, Silva-Santos B. CD70-CD27 interactions provide survival and proliferative signals that regulate $\mathrm{T}$ cell receptor-driven activation of human $\gamma \delta$ peripheral blood lymphocytes. Eur J Immunol. (2011) 41:195-201. doi: 10.1002/eji.2010 40905
22. Ribot JC, deBarros A, Silva-Santos B. Searching for "signal 2": costimulation requirements of $\gamma \delta \mathrm{T}$ cells. Cell Mol Life Sci. (2011) 68:2345-55. doi: 10.1007/s00018-011-0698-2

23. Rhodes DA. Reith W, Trowsdale J. Regulation of immunity by butyrophilins. Ann Rev Immunol. (2016) 34:151-72. doi: 10.1146/annurev-immunol-041015-055435

24. Wesch D, Peters C, Oberg HH, Pietschmann K, Kabelitz D. Modulation of $\gamma \delta \mathrm{T}$ cell responses by TLR ligands. Cell Mol Life Sci. (2011) 68:2357-70. doi: 10.1007/s00018-011-0699-1

25. Dudal S, Turriere C, Bessoles S, Fontes P, Sanchez F, Liautard J, et al. Release of LL-37 by activated human V V $9 \mathrm{~V} \delta 2 \mathrm{~T}$ cells: a microbicidal weapon against Brucella suis. J Immunol. (2006) 177:5533-9. doi: 10.4049/jimmunol.177.8.5533

26. Hamada S, Umemura M, Shiono T, Tanaka K, Yahagi A, Begum MD, et al. IL-17A produced by $\gamma \delta \mathrm{T}$ cells plays a critical role in innate immunity against Listeria monocytogenes infection in the liver. J Immunol. (2008) 181:3456-63. doi: 10.4049/jimmunol.181.5.3456

27. Harly C, Peigné C, Scotet E. Molecules and mechanisms implicated in the peculiar antigenic activation process of human $\mathrm{V} \gamma 9 \mathrm{~V} \delta 2 \mathrm{~T}$ cells. Front Immunol. (2015) 5:657. doi: 10.3389/fimmu.2014. 00657

28. Sutton CE, Mielke LA, Milles KH. IL-17 producing $\gamma \delta \mathrm{T}$ cells and innate lymphoid cells. Eur J Immunol. (2012) 42:2221-31. doi: 10.1002/eji.201242569

29. Sabbione F, Gabelloni ML, Ernst G, Gori MS, Salamone GV, Oleastro M, et al. Neutrophils suppress $\gamma \delta$ T-cell function. Eur J Immunol. (2014) 44:819-30. doi: 10.1002/eji.201343664

30. Towstyka NY, Shiromizu CM, Keitelman I, Sabbione F, Salamone GV, Geffner JR, et al. Modulation of $\gamma \delta$ T-cell activation by neutrophil elastase. Immunology (2018) 153:225-37. doi: 10.1111/imm.12835

31. Kalyan S, Kabelitz D. Defining the nature of human $\gamma \delta$ T cells: a biographical sketch of the highly empathetic. Cell Mol Immunol. (2013) 10:21-9. doi: $10.1038 / \mathrm{cmi} .2012 .44$

32. Hintz M, Reichenberg A, Altincicek B, Bahr U, Gschwind RM, Kollas AK, et al. Identification of (E)-4-hydroxy-3-methyl-but-2-enyl pyrophosphate as a major activator for human $\gamma \delta$ T cells in Escherichia coli. FEBS Lett (2001) 509:317-22. doi: 10.1016/S0014-5793(01)03191-X

33. Eberl M, Hintz M, Reichenberg A, Kollas AK, Wiesner J, Jomaa H. Microbial isoprenoid biosynthesis and human $\gamma \delta \mathrm{T}$ cell activation. FEBS Lett. (2003) 544:4-10. doi: 10.1016/S0014-5793(03)00483-6

34. Belmant C, Espinosa E, Poupot R, Peyrat MA, Guiraud M, Poquet Y, et al. 3Formyl-1-butyl pyrophosphate: a novel mycobacterial metabolite-activating human $\gamma \delta$ T cells. J Biol Chem. (1999) 274:32079-84

35. Poggi A, Catellan S, Musso A, Zocchi MR. $\gamma \delta$ T lymphocytes producing IFN- $\gamma$ and IL-17 in response to Candida albicans or mycobacterial antigens: possible implications for acute and chronic inflammation. Curr Med Chem. (2009) 16:4743-9. doi: 10.2174/092986709789878238

36. Shen Y, Zhou D, Qiu L, Lai X, Simon M, Shen L, et al. Adaptive immune response of $\mathrm{V} \gamma 2 \mathrm{~V} \delta 2+\mathrm{T}$ cells during mycobacterial infections. Science (2002) 295:2255-8. doi: 10.1126/science.1068819

37. Huang D, Shen Y, Qiu L, Chen CY, Shen L, Estep J, et al. Immune distribution and localization of phosphoantigen-specific V $\gamma 2 \mathrm{~V} \delta 2 \mathrm{~T}$ cells in lymphoid and nonlymphoid tissues in Mycobacterium tuberculosis Infection. Infect Immun. (2007) 76:426-36. doi: 10.1128/IAI.01008-07

38. Qiu L, Huang D, Chen CY, Wang R, Shen L, Shen Y, et al. Severe tuberculosis induces unbalanced up-regulation of gene networks and overexpression of IL22, MIP-1 $\alpha$, CCL27, IP-10, CCR4, CCR5, CXCR3, PD1, PDL2, IL-3, IFNbeta, TIM1, and TLR2 but low antigen-specific cellular responses. J Infect Dis. (2008) 198:1514-9. doi: 10.1086/592448

39. Ravens S, Hengst J, Schlapphoff V, Deterding K, Dhingra A, SchultzeFlorey $\mathrm{C}$, et al. Human $\gamma \delta \mathrm{T}$ cell receptor repertoires in peripheral blood remain stable despite clearance of persistent hepatitis $\mathrm{C}$ virus infection by direct-acting antiviral drug therapy. Front Immunol. (2018) 9:510. doi: 10.3389/fimmu.2018.00510

40. Tseng CTK, Miskovsky E, Houghton M, Klimpel GR. Characterization of liver T-cell receptor $\gamma \delta \mathrm{T}$ cells obtained from individuals chronically infected with hepatitis $\mathrm{C}$ virus (HCV): evidence for these $\mathrm{T}$ cells playing a role in the liver pathology associated with HCV infections. Hepatology (2001) 33:1312-20. doi: $10.1053 /$ jhep.2001.24269 
41. Agrati C, D’Offizi G, Narciso P, Abrignani S, Ippolito G, Colizzi V, et al. $\mathrm{V} \delta 1 \mathrm{~T}$ lymphocytes expressing aTh1 phenotype are the major $\gamma \delta \mathrm{T}$ cell subset infiltrating the liver of HCV-infected persons. Mol Med. (2001) 7:11-9.

42. Agrati C, Alonzi T, De Santis R, Castilletti C, Abbate I, Capobianchi MR, et al. Activation of $\mathrm{V} \gamma 9 \mathrm{~V} \delta 2 \mathrm{~T}$ cells by non-peptidic antigens induces the inhibition of subgenomic HCV replication. Int Immunol. (2006) 18:11-8. doi: $10.1093 /$ intimm/dxh337

43. Rajoriya N, Fergusson JR, Leithead JA, Klenerman P. $\gamma \delta$ T-lymphocytes in hepatitis C and chronic liver disease. Front Immunol. (2014) 5:1-9. doi: 10.3389/fimmu.2014.00400

44. Nishimura H, Yajima T, Kagimoto Y, Ohata M, Watase T, Kishihara K, et al. Intraepithelial $\gamma \delta \mathrm{T}$ cells may bridge a gap between innate immunity and acquired immunity to herpes simplex virus type 2. J Virol. (2004) 78:4927-30. doi: 10.1128/JVI.78.9.4927-4930.2004

45. Wang T, Gao Y, Scully E, Davis CT, Anderson JF, Welte T, et al. $\gamma \delta \mathrm{T}$ cells facilitate adaptive immunity against West Nile virus infection in mice. $J$ Immunol. (2006) 177:1825-32. doi: 10.4049/jimmunol.177.3.1825

46. Vermijlen D, Brouwer M, Donner C, Liesnard C, Tackoen M, Van Rysselberge $\mathrm{M}$, et al. Human cytomegalovirus elicits fetal $\gamma \delta \mathrm{T}$ cell responses in utero. $J$ Exp Med. (2010) 207:807-21. doi: 10.1084/jem.20090348

47. Fenoglio D, Poggi A, Catellani S, Battaglia F, Ferrera A, Setti M, et al. $\mathrm{V} \delta 1 \mathrm{~T}$ lymphocytes producing IFN- $\gamma$ and IL-17 are expanded in HIV-1infected patients and respond to Candida albicans. Blood (2009) 113:6611-8. doi: 10.1182/blood-2009-01-198028

48. Sicard H, Ingoure S, Luciani B, Serraz C, Fournié JJ, Bonneville M, et al. In vivo immunomanipulation of $\mathrm{V} \gamma 9 \mathrm{~V} \delta 2 \mathrm{~T}$ cells with a synthetic phosphoantigen in a preclinical nonhuman primate model. J Immunol. (2005) 175:5471-80. doi: 10.4049/jimmunol.175.8.5471

49. Huang D, Chen CY, Ali Z, Shao L, Shen L, Lockman HA, et al. Antigenspecific $\mathrm{V} \gamma 2 \mathrm{~V} \delta 2 \mathrm{~T}$ effector cells confer homeostatic protection against pneumonic plaque lesions. Proc Natl Acad Sci USA. (2009) 106:7553-8. doi: 10.1073/pnas.0811250106

50. Par G, Rukavina D, Podack ER, Horanyi M, Szekeres-Bartho J, Hegedüs G, et al. Decrease in CD3-negative-CD8 $\mathrm{dim}^{+}$and $\mathrm{V} \delta 2 / \mathrm{V} \gamma 9 \mathrm{TcR}+$ peripheral blood lymphocyte counts, low perforin expression and the impairment of natural killer cell activity is associated with chronic hepatitis $\mathrm{C}$ virus infection. J Hepatol. (2002) 37:514-22. doi: 10.1016/S0168-8278(02)00218-0

51. Riedel DJ, Sajadi M, Armstrong CL,Cummings JS, Cairo C, Redfield RR, et al. Natural viral suppressors of HIV-1 have a unique capacity to maintain $\gamma \delta \mathrm{T}$ cells. AIDS (2009) 23:1955-64. doi: 10.1097/QAD.0b013e32832ff1ff

52. Cimini E, Bonnafous C, Bordoni V, Lalle E, Sicard H, Sacchi A, et al. Interferon- $\alpha$ improves phosphoantigen-induced $\mathrm{V} \gamma 9 \mathrm{~V} \delta 2 \mathrm{~T}$-cells interferon$\gamma$ production during chronic HCV infection. PLoS ONE (2012) 7:e37014. doi: 10.1371/journal.pone.0037014

53. Isailovic N, Daigo K, Mantovani A, Selmi C. Interleukin-17 and innate immunity in infections and chronic inflammation. J Autoimmun. (2015) 60:1-11. doi: 10.1016/j.jaut.2015.04.006

54. Burkett PR, Meyer zu Horste G, Kuchroo VK. Pouring fuel on the fire: Th17 cells, the environment, and autoimmunity. J Clin Invest. (2015) 125:2211-9. doi: 10.1172/JCI78085

55. Hirota K, Duarte JH, Veldhoen M, Hornsby E, Li Y, Cua DJ, et al. Fate mapping of IL-17-producing T cells in inflammatory responses. Nat Immunol. (2011) 12:255-63. doi: 10.1038/ni.1993

56. Papotto PH, Reinhardt A, Prinz I, Silva-Santos B. Innately versatile: $\gamma \delta 17 \mathrm{~T}$ cells in inflammatory and autoimmune diseases. J Autoimmun. (2018) 87:26-37. doi: 10.1016/j.jaut.2017.11.006

57. Caccamo N, Le Mendola C, Orland V, Meraviglia S, Todaro M, Stassi G, et al. Differentiation, phenotype and function of interleukin-17-producing human

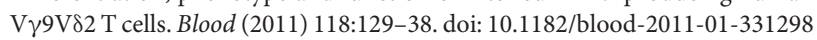

58. Moens E, Brouwer M, Dimova T, Goldman M, Willems F, Vermijlen D. IL$23 \mathrm{R}$ and TCR signaling drives the generation of neonatal $\mathrm{V} \gamma 9 \mathrm{~V} \delta 2 \mathrm{~T}$ cells expressing high levels of cytotoxic mediators and producing IFN- $\gamma$ and IL-17. J Leuk Biol. (2011) 89:743-52. doi: 10.1189/jlb.0910501

59. Jameson J, Ugarte K, Chen N, Yachi P, Fuchs E, Boismenu R, et al. A role for skin $\gamma \delta \mathrm{T}$ cells in wound repair. Science (2002) 296:747-49. doi: 10.1126/science.1069639

60. Hayday AC. $\gamma \delta \mathrm{T}$ cells and the lymphoid stress-surveillance response. Immunity (2009) 31:184-96. doi: 10.1016/j.immuni.2009.08.006
61. Holtmeier W, Pfänder M, Hennemann A, Caspary WF, Zollner TM, Kaufmann R. The TCR- $\delta$ repertoire in normal human skin is restricted and distinct from the TCR- $\delta$ repertoire in the peripheral blood. $J$ Invest Dermatol. (2001) 116:275-90. doi: 10.1046/j.1523-1747.2001.01 250.x

62. Chan JR, Blumenschein W, Murphy E, Diveu C, Wiekowski M, Abbondanzo S, et al. IL-23 stimulates epidermal hyperplasia via TNF and IL-20R2dependent mechanisms with implications for psoriasis pathogenesis. J Exp Med. (2006) 203:2577-87. doi: 10.1084/jem.20060244

63. Cai Y, Shen X, Ding C, Qi C, Li K, Li X, et al. Pivotal role of dermal IL17-producing $\gamma \delta \mathrm{T}$ cells in skin inflammation. Immunity (2011) 35:596-610. doi: 10.1016/j.immuni.2011.08.001

64. Diani M, Altomare G, Reali E. $T$ cell responses in psoriasis and psoriatic arthritis. Autoimmun Rev. (2015) 14:286-92. doi: 10.1016/j.autrev.2014.11.012

65. Pantelyushin S, Haak S, Ingold B, Kulig P, Heppner FL, Navarini AA, et al. Ror $\gamma+$ innate lymphocytes and $\gamma \delta \mathrm{T}$ cells initiate psoriasiform plaque formation in mice. J Clin Invest. (2012) 122:2252-6. doi: 10.1172/JCI61862

66. Laggner U, Di Meglio P, Perera GK, Hundhausen C, Lacy KE, Ali N, et al. Identification of a novel proinflammatory human skin-homing V $\gamma 9 \mathrm{~V} \delta 2 \mathrm{~T}$ cell subset with a potential role in psoriasis. J Immunol. (2011) 187:2783-93. doi: 10.4049/jimmunol.1100804

67. O'Brien RL, Born WK. Dermal $\gamma \delta \mathrm{T}$ cells - What have we learned? Cell Immunol. (2015) 296:62-9. doi: 10.1016/j.cellimm.2015.01.011

68. Teng MW, Bowman EP, McElwee JJ, Smyth MJ, Casanova JL, Cooper AM, et al. IL-12 and IL-23 cytokines: from discovery to targeted therapies for immune-mediated inflammatory diseases. Nat Med. (2015) 21:719-29. doi: 10.1038/nm.3895

69. Kirkham BW, Kavanaugh A, Reich K. Interleukin-17A: a unique pathway in immune-mediated diseases: psoriasis, psoriatic arthritis and rheumatoid arthritis. Immunology (2014) 141:133-42. doi: 10.1111/imm.12142

70. Freedman MS, Ruijs TC, Selin LK, Antel JP. Peripheral blood $\gamma \delta$ T cells lyse fresh human braindderived oligodendrocytes. Ann Neurol. (1991) 30:794-800.

71. Zeine R, Pon R, Ladiwala U, Antel JP, Filion LG, Freedman MS. Mechanism of $\gamma \delta \mathrm{T}$ cell-induced human oligodendrocyte cytotoxicity: relevance to multiple sclerosis. J Neuroimmunol. (1998) 87:49-61.

72. Schirmer L, Rothhammer V, Hemmer B. Enriched CD161high CCR6 $+\gamma \delta$ $\mathrm{T}$ cells in the cerebrospinal fluid of patients with multiple sclerosis. JAMA Neurol. (2013) 70:345-51. doi: 10.1001/2013.jamaneurol.409

73. Tzartos JS, Friese MA, Craner MJ, Palace J, Newcombe J, Esiri MM, et al. Interleukin-17 production in central nervous system-infiltrating $\mathrm{T}$ cells and glial cells is associated with active disease in multiple sclerosis. Am J Pathol. (2008) 172:146-55. doi: 10.2353/ajpath.2008.070690

74. Kurasawa K, Hirose K, Sano H, Endo H, Shinkai H, Nawata Y, et al. Increased interleukin-17 production in patients with systemic sclerosis. Arthritis Rheum. (2000) 43:2455-63. doi: 10.1002/1529-0131(200011)43:11<2455::AIDANR12>3.0.CO;2-K

75. Maimaitijiang G, Shinoda K, Nakamura Y, Masaki K, Matsushita T, Isobe $\mathrm{N}$, et al. Association of decreased percentage of $\mathrm{V} \delta 2+\mathrm{V} \gamma 9+\gamma \delta \mathrm{T}$ cells with disease severity in multiple sclerosis. Front Immunol. (2018) 9:748. doi: 10.3389/fimmu.2018.00748

76. Blink SE, Caldis MW, Goings GE, Harp CT, Malissen B, Prinz I, et al. $\gamma \delta \mathrm{T}$ cell subsets play opposing roles in regulating experimental autoimmune encephalomyelitis. Cell Immunol. (2014) 290:39-51. doi: 10.1016/j.cellimm.2014.04.013

77. Lalor SJ, Dungan LS, Sutton CE, Basdeo SA, Fletcher JM, Mills KH. Caspase1-processed cytokines IL-1 $\beta$ and IL-18 promote IL-17 production by $\gamma \delta$ and CD4 T cells that mediate autoimmunity. J Immunol. (2011) 186:5738-48. doi: 10.4049/jimmunol.1003597

78. Wohler JE, Smith SS, Zinn KR, Bullard DC, Barnum SR. $\gamma \delta$ T cells in EAE: early trafficking events and cytokine requirements. Eur J Immunol. (2009) 39:1516-26. doi: 10.1002/eji.200839176

79. Papotto PH, Ribot JC, Silva-Santos B. IL-17 $+\gamma \delta$ T cells as kick-starters of inflammation. Nat Immunol. (2017) 18:604-11. doi: 10.1038/ni.3726

80. Ottum PA, Arellano G, Reyes LI, Iruretagoyena M, Naves R. Opposing roles of interferon- $\gamma$ on cells of the central nervous system in autoimmune neuroinflammation. Front Immunol. (2015) 6:539. doi: $10.3389 /$ fimmu.2015.00539 
81. Rajan AJ, Gao Y, Raine CS, Brosnan CF. A pathogenic role for $\gamma \delta \mathrm{T}$ cells in relapsing-remitting experimental allergic encephalomyelitis in the SJL mouse. J Immunol. (1996) 157:941-49.

82. Sutton C, Brereton C, Keogh B, Mills KH, Lavelle EC. A crucial role for interleukin (IL)-1 in the induction of IL-17 producing $\mathrm{T}$ cells that mediate autoimmune encephalomyelitis. J Exp Med. (2006) 203:1685-91. doi: $10.1084 / \mathrm{jem} .20060285$

83. Raverdeau M, Breen CJ, Misiak A, Mills KH. Retinoic acid suppresses IL17 production and pathogenic activity of $\gamma \delta \mathrm{T}$ cells in CNS autoimmunity. Immuno Cell Biol. (2016) 94:763-73. doi: 10.1038/icb.2016.39
Conflict of Interest Statement: The authors declare that the research was conducted in the absence of any commercial or financial relationships that could be construed as a potential conflict of interest.

Copyright $\odot 2018$ Shiromizu and Jancic. This is an open-access article distributed under the terms of the Creative Commons Attribution License (CC BY). The use, distribution or reproduction in other forums is permitted, provided the original author(s) and the copyright owner(s) are credited and that the original publication in this journal is cited, in accordance with accepted academic practice. No use, distribution or reproduction is permitted which does not comply with these terms. 